\title{
PENDIDIKAN MUSIK SEBAGAI SARANA PENGEMBANGAN KREATIVITAS REMAJA GEREJA MASEHI INJILI DI MINAHASA
}

\author{
${ }^{1}$ Stefanny Mersiany Pandaleke, ${ }^{2}$ Fian Panekenan \\ ${ }^{1}$ Dosen Pendidikan Musik Gereja IAKN Manado , ${ }^{2}$ Mahasiwa Pendidikan Musik Gereja \\ IAKN Manado \\ 1 stefanny@iakn-manado.ac.id, ${ }^{2}$ fnpanekenan@gmail.com
}

\begin{abstract}
Abstrak
Remaja Gereja Masehi Injili di Minahasa (GMIM) merupakan generasi penerus gereja yang berusia peralihan dari anak sekolah minggu dan menuju usia pemuda. Dalam melaksanakan kegiatannya, pendidikan musik hadir sebagai media apresiasi dan pengembangan kreativitas. Tulisan ini membahas mengenai proses pendidikan musik di lingkungan GMIM yang bertindak sebagai alat pendidikan kreasi bagi remaja. Tujuan penelitian ini adalah memahami dan menjelaskan bagaimana pendidikan musik diwujudkan sebagai sarana pengembangan kreativitas bagi remaja GMIM. Penelitian ini menggunakan metode kualitatif, dengan teknik pengumpulan data melalui observasi, wawancaran dan studi dokumen. Analisis data menggunakan konsep apresiasi dan kreasi dalam ranah pendidikan seni, dengan mengikuti alur analisis model interaktif. Hasil penelitian menunjukkan bahwa remaja GMIM terlibat langsung dalam proses apresiasi melalui kegiatan remaja tingkat jemaat, wilayah dan sinode, yang didominasi dengan aktivitas bermusik. Proses apresiasi dilaksanakan ke dalam lima tahap, yang dimulai sejal pengenalan awal hingga penilaian. Berangkat dari kegiatan apresiasi, maka remaja GMIM melakukan pengembangan kreativitas, melalui tahap persiapan, mengkonsep ide hingga penuangan ide kreatif.
\end{abstract}

Kata kunci: Pendidikan Musik, Kreativitas, Remaja GMIM

\section{MUSIC EDUCATION AS A MEANS OF DEVELOPMENT OF ADOLESCENT CHILDREN'S CHILDREN CHURCHES IN EVOLUTION IN MINAHASA}

\begin{abstract}
The teenagers of Evangelical Christian Church in Minahasa (GMIM) are the next church's generation who are transitioning from sunday school group to youth. In their activities, music education exists as a medium of appreciation and development of creativity. This paper discusses about the process of music education in GMIM which acts as a education creativity for teenagers. The purpose of this research is to understand and explain how music education is realized as a medium of developing creativity for GMIM teenagers. This research uses qualitative method, with data collected by observation, interviews and document studies. The data analysis uses appreciation and creation concept in art education, by following the interactive model analysis. The results showed that GMIM teenagers were directly involved in the appreciation process through the their activities in congregation, regional and synod level, which were dominated by musical activities. The process of appreciation is implemented into five phase, that starting from introduction to assessment. Stand on the appreciation activites, GMIM teenagers did the development of creativity, through the preparation, conceptualizing ideas and pouring creativ ideas.
\end{abstract}

Keywords: Music Education, Creativity, GMIM Teenagers 


\section{Pendahuluan}

Proses pendidikan berperan
penting bagi kehidupan manusia, termasuk pembentukan kepribadian generasi muda. Beragam jenis pendidikan yang bisa dijalani oleh generasi muda, termasuk kalangan remaja, meliputi pendidikan formal maupun non formal. Bertumbuh pada era digital, menjadikan generasi muda beradaptasi dengan sistem pendidikan yang serba cepat dan terbuka. Sejalan dengan penjelasan Grafura dan Wijayanti ${ }^{1}$ bahwa generasi digital memiliki kelebihan diantaranya sangat peduli terhadap identitas diri, memiliki semangat ingin mengetahui banyak hal, generasi multitasking, gagasan dan ide yang dapat melampaui imaji.

Sebagai salah satu cabang seni, musik menempati posisi krusial dalam kultur pendidikan. Musik sebagai alat pendidikan berperan penting dalam pertumbuhan kreativitas seseorang. Berawal dari proses apresiasi menjadikan seseorang mengalami pengalaman estetis sehingga mampu merangsang prosesproses kreatif pada masing-masing individu maupun kelompok. Proses pendidikan musik tersebut tidak hanya terjadi pada lembaga pendidikan formal, tetapi juga terlaksana di ruang lingkup gereja.

Pendidikan musik di gereja, khususnya di kota Manado dan sekitarnya, semakin gencar dilaksanakan dari tahun ke tahun. Dikenal dengan istilah kota paduan suara, menjadikan masyarakat lekat dengan aktivitasaktivitas paduan suara. Bermula dari kegiatan paduan suara di gereja-gereja, kemudian merambat pada kegiatankegiatan paduan suara kota/kabupaten, kecamatan dan kelurahan maupun komunitas-komunitas tertentu. Setiap tahun, kegiatan paduan suara

${ }^{1}$ Lubis Grafura \& Ari Wijiyanti, Spirit Pedagogi di Era Disrupsi, (Yogyakarta: 2019) hlm 18-23. dilaksanakan berupa festival, lomba, pelatihan-pelatihan dan konser.

Khusus untuk Gereja Masehi Injili di Minahasa (GMIM), aktivitas paduan suara sudah dilmulai sejak Anak Sekolah Minggu (ASM), remaja, pemuda, bapak/ibu bahkan lansia. Hal ini menandakan bahwa terjadi proses pendidikan musik di masing-masing gereja. Memulai aktivitas paduan suara berarti memulai suatu proses latihan panjang dari hari ke hari. Hal tersebut merupakan suatu proses pendidikan yang dilaksanakan di lingkungan gereja melalui musik.

Di lingkungan GMIM, remaja sebagai generasi muda yang berada di antara usia anak sekolah minggu dan pemuda, diperlengkapi dengan beragam kegiatan sinode gereja. Berdasarkan Tata Gereja Masehi Injili di Minahasa tahun 2014 dijelaskan bahwa remaja GMIM adalah anggota GMIM yang berusia 12-16 tahun, atau bisa juga yang duduk di SLTP/SMP dan SMA, dan belum mengikuti kegiatan-kegiatan pemuda. Dengan rentang usia yang cukup pendek, aktivitas kegiatan gereja yang ditawarkan pada pelayanan kategorial remaja tergolong tinggi. Tingginya aktivitas tersebut membuat remaja-remaja GMIM berperan aktif pada kegiatan-kegiatan gereja mulai dari tingkat jemaat, wilayah dan sinode, tidak terkecuali pada aktivitas bermusik.

Aktivitas lomba atau kegiatankegiatan remaja GMIM tingkat sinode, meliputi Pesta Seni Remaja (PSR), Hari Persatuan Remaja GMIM (HPRG), perkemahan remaja, Remaja Teladan (Retel), selebrasi paskah, natal remaja dan sebagainya, menjadikan remaja gereja berkembang dan bertumbuh di lingkungan gereja. Selain dididik di keluarga masing-masing dan sekolah, lingkungan gereja juga menjadi bagian penting yang mempengaruhi perkembangan remaja tersebut. Seperti 
dijelaskan Lickona $^{2}$ bahwa pendidikan karakter yang diwujudkan melalui pendidikan nilai bagi kaum muda, merupakan upaya kerjasama antara sekolah dan keluarga. Untuk mewujudkannya, perlu keterlibatan lembaga-lembaga pendidikan, termasuk gereja. Bisa dikatakan bahwa kegiatan sinodal untuk remaja dirancang dari awal tahun hingga akhir tahun. Dapat dibayangkan selama kurang lebih 4-5 tahun, pertumbuhan dan perkembangan remaja juga didominasi pada proses pendidikan di lingkungan gereja.

Berbagai aktivitas remaja sinode mendukung hadirnya pendidikan musik di lingkungan remaja GMIM. Berkembangnya berbagai lomba, festival, konser berupa paduan suara, vokal grup, menyanyi solo, busana gereja, talent show remaja teladan menuntut remaja GMIM meluangkan waktunya untuk berproses dalam latihan. Tuntutan proses latihan di masing-masing gereja, baik tingkat jemaat maupun wilayah, saat ini lazim dilaksanakan. Aktivitas latihan tersebut tidak lepas dengan terlaksananya aktivitas bermusik, sekalipun kegiatan tersebut bukan ditujukan untuk lomba bermusik.

Berdasarkan uraian tersebut, maka peneliti berusaha untuk mengungkap dan menjelaskan bahwa pendidikan musik juga hadir di lingkungan gereja yang bertindak sebagai alat pendidikan kreasi bagi remaja. Tujuan penelitian ini adalah memahami dan menjelaskan bagaimana pendidikan musik diwujudkan sebagai sarana pengembangan kreativitas bagi remaja GMIM. Guna membingkai penelitian ini, maka pembahasan diuraikan berpijak pada konsep apresiasi dan kreasi dalam pendidikan seni yang diuraikan Jazuli. Jazuli menjelaskan bahwa untuk memperoleh pengalaman

\footnotetext{
${ }^{2}$ Thomas Lickona, Pendidikan Karakter: Panduan Lengkap Mendidik Siswa Menjadi Pintar dan Baik, (Bandung: 2014) hlm 50.
}

estetik dalam ranah pendidikan seni, harus melalui kegiatan apresiasi dan kreasi yang dieskpresikan. Proses apresiasi dapat dilaksanakan dalam beberapa tahap, yaitu tahap pengamatan, penikmatan, pemahaman, penghayatan dan penilaian. Berangkat dari kegiatan apresiasi, maka seseorang dapat melaksanakan kegiatan kreasi. Kreativitas dalam ranah pendidikan seni sangat vital, yakni dilaksanakan melalui eksplorasi, eksperimen dan evaluasi pada proses maupun hasil kreasinya, keterampilan dan keahlian motorik, penampilan dan afeksi yang menyertai kegiatan kreasi. ${ }^{3}$

Konsep kreativitas juga didukung dengan konsep proses berpikir kreatif dari Wallas, yang menerangkan bahwa terdapat 4 (empat) tahap dalam proses berpikir kreatif. Proses berpikir kreatif dijabarkan dalam 4 (empat) tahap, yaitu tahap persiapan, tahap inkubasi, tahap iluminasi dan verifikasi. $^{4}$ Sunarto $^{5}$ (2018:108) juga menjelaskan dalam artikelnya bahwa kreativitas dapat diuraikan sebagai (1) kemampuan menanggapi dan memberi solusi, (2) kemampuan melibatkan diri dalam proses penemuan suatu masalah, kemampuan intelegensi, gaya kognitif dan kepribadian, (4) kemampuan dalam menghasilkan daya cipta yang baru.

\section{Metode}

Metode yang digunakan dalam penelitian ini adalah metode kualitatif dengan pendekatan pendidikan seni. Penelitian ini dilaksanakan di beberapa wilayah Gereja Masehi Injili di Minahasa,

\footnotetext{
${ }^{3}$ Jazuli, Paradigma Pendidikan Seni,

Semarang: CV. Farishma Indonesia, 2016, hlm. 77-99.

${ }^{4}$ Graham Wallas, The Art of Thought, England: Solis Press, 2014.

${ }^{5}$ Sunarto, "Pengembangan Kreativitas-Inovatif dalam Pendidikan Seni Melalui Pembelajaran Mukidi”, Jurnal Refleksi Edutika Vol. 8 No. 2, 2018, hlm. 108.
} 
diantaranya Wilayah Mapanget Satu kota Manado dan Wilayah Amurang Dua Minahasa Selatan. Sasaran yang dikaji adalah kreativitas remaja GMIM melalui pendidikan musik. Pengumpulan data dilakukan melalui observasi atau pengamatan secara langsung ke gerejagereja dan tempat berkegiatan remaja GMIM tingkat sinode, wilayah maupun jemaat. Wawancara yang ditujukan kepada narasumber, antara lain Komisi Pelayanan Remaja tingkat jemaat maupun wilayah, pembina-pembina remaja dan remaja GMIM pada umumnya. Sementara studi dokumen yang dikumpulkan melalui pamflet/poster kegiatan-kegiatan remaja, media sosial, panduan atau juknis kegiatan-kegiatan remaja sinode GMIM, dokumentasi foto dan video kegiatankegiatan remaja tingkat jemaat, wilayah dan sinode. Teknik analisis data menggunakan konsep apresiasi dan kreasi dalam ranah pendidikan seni, dengan mengikuti alur analisis model interaktif, yakni pengumpulan data, reduksi data, penyajian dan verifikasi data.

\section{Hasil dan Pembahasan}

\section{Aktivitas bermusik remaja GMIM}

Musik dalam kehidupan bergereja menjadi sebuah aktivitas penting, baik dalam peribadatan, kegiatan-kegiatan tingkat jemaat, wilayah maupun sinode. Berdiri di Minahasa dengan budaya masyarakat yang bernyanyi, Gereja Masehi Injili di Minahasa (GMIM) sangat erat dengan nyanyian-nyanyian. Setiap peribadatan GMIM, selalu didahului dan didominasi dengan nyanyian. Ini juga terlihat pada lomba-lomba sinode GMIM, mulai dari anak sekolah minggu, remaja/pemuda, bapak/ibu bahkan pelayan khusus.

Berada di masa peralihan, remaja gereja merupakan ujung tombak gereja di masa depan. Karena itu, pentingnya proses pertumbuhan melalui pendidikan di gereja. Aktivitas bermusik remaja GMIM merupakan aktivitas yang sering dilaksanakan pada setiap ibadah, kegiatan jemaat, lomba-lomba wilayah/sinode dan konser. Seperti yang ditegaskan Chrisnahanungkara ${ }^{6}$ bahwa pendidikan seni musik dalam gereja mengambil peran penting sebagai upaya memanusiakan manusia, diantaranya menyeimbangkan potensi yang dimiliki melalui musik. Kegiatan berkesenian dalam gereja akan membantu remaja GMIM meningkatkan aspek estetis.

Berbagai kegiatan sinode, wilayah maupun jemaat GMIM, dapat memfasilitasi proses pendidikan musik, melalui aktivitas-aktivitas bermusik remaja GMIM, yang dapat diuraikan sebagai berikut.

\section{Paduan Suara Remaja GMIM}

Paduan suara remaja GMIM merupakan kegiatan yang paling diminati oleh remaja. Setiap jemaat GMIM cenderung memiliki kelompok paduan suara remaja. Paduan suara remaja GMIM menjadi suatu kebutuhan, diantaranya karena hadirnya lomba Pesta Seni Remaja (PSR) yang dilaksanakan setiap tahun. Hal ini tentu membuat setiap kelompok paduan suara memiliki waktu latihan. Umumnya, latihan paduan suara dilaksanakan tiga hingga empat kali dalam seminggu. Dalam buku Musik dalam Ibadah dijelaskan bahwa kiat menyelenggarakan latihan paduan suara terdiri dari tahap persiapan sebelum latihan, vokalisi, latihan lagu, pembentukan komunitas dan formasi spiritual. $^{7}$

Proses latihan paduan suara umumnya terbagi dua, yaitu latihan per suara dan latihan bersama. Dalam proses

\footnotetext{
${ }^{6}$ Ariel J. Chrisnahanungkara, "Gereja dan Pendidikan Seni Musik Bagi Anak", Jurnal Tonika Vol. 2 No. 1, 2019, hlm. 71.

${ }^{7}$ Komisi Liturgi dan Musik Sinode GKI, Musik dalam Ibadah, (Jakarta:2012)
} 
latihan, selain remaja diajarkan teknik bernyanyi, remaja GMIM juga diajarkan kedisiplinan waktu, saling mendengar dan menghargai, membaca notasi dan belajar lagu-lagu. Latihan paduan suara diawali dengan doa, kemudian warming up yang dipimpin oleh pelatih atau anggota remaja yang dipilih pelatih dengan bergantian setiap kali latihan.

Selain dipersiapkan untuk mengikuti lomba PSR, paduan suara remaja GMIM juga menempuh latihan untuk persiapan pelayanan di ibadahibadah jemaat dan kegiatan hari-hari raya gerejawi. Sebelum tampil dalam pelayanan maupun lomba, paduan suara remaja GMIM melakukan persiapan yang cukup panjang bahkan hingga berbulanbulan. Setiap selesai kegiatan lomba maupun pelayanan, maka diadakan evaluasi untuk perbaikan lebih lanjut, baik dari pelatih, anggota remaja yang terlibat dalam paduan suara, pembina remaja dan orang tua.

\section{Vokal Grup Remaja GMIM}

Vokal grup remaja GMIM juga merupakan aktivitas bermusik dalam ibadah maupun lomba. Selain paduan suara, vokal grup juga digemari oleh anggota remaja GMIM. Hal ini dibuktikkan dengan hadirnya vokal grup remaja di setiap jemaat GMIM. Vokal grup remaja GMIM biasanya terdiri dari 8-12 orang, termasuk pengiring. Pengiring bisa dari pelatih maupun remaja yang sudah mahir bermain instrumen musik.

Seperti paduan suara, anggota vokal grup juga melaksanakan proses latihan demi terciptanya vokal grup yang kompak dan harmonis. Umumnya, latihan vokal grup dilaksanakan dua hingga tiga kali dalam seminggu. Beberapa hal yang dilatih dalam proses latihan vokal grup, antara lain teknik bernyanyi, pembagian suara, improvisasi dan penggunaan koreografi. Hal-hal kontesktual yang termasuk dalam aktivitas latihan vokal grup, yakni disiplin waktu, saling menghargai dan saling menyeimbangi. Vokal grup remaja GMIM biasanya dipersiapkan untuk mengikuti lomba sinode GMIM dalam Pesta Seni Remaja, serta dipersiapkan dalam pelayanan ibadah gereja dan hari-hari raya gerejawi.

\section{Bernyanyi dan Bermain Musik dalam Peribadatan}

Menyanyi dan mengiringi melalui instrumen musik dalam peribadatan merupakan hal yang wajib dilaksanakan setiap peribadatan jemaat, terutama ibadah minggu. Sejalan dengan yang dikatakan Abineno $^{8}$ bahwa nyanyian jemaat menduduki tempat penting dalam ibadah sejak dahulu hingga saat ini. Itulah sebabnya pemimpin nyanyian/pujian dan pengiring musik dalam ibadah-ibadah gereja harus ada regenerasi dari satu generasi ke generasi berikutnya.

Sebagai generasi penerus gereja, maka remaja GMIM juga aktif dalam pelayanan pujian di ibadah-ibadah gereja. Pada beberapa gereja wilayah GMIM Mapanget 1 , anggota remaja yang berusia 15-16 tahun dipersiapkan dan dilatih untuk menjadi kantoria jemaat. Begitu juga dengan pengiring, remaja-remaja dipersiapkan untuk menjadi pengiring dalam ibadah umum maupun ibadah remaja tingkat jemaat melalui piano dan gitar. Selain sebagai kantoria/singers dan pengiring, aktivitas bernyanyi juga dialami oleh semua remaja GMIM dalam setiap ibadah remaja, diantaranya ibadah remaja/pemuda kolom, ibadah remaja tingkat jemaat dan wilayah, serta ibadah remaja tingkat sinode. Karena itu, aktivitas bermusik remaja GMIM tidak hanya dilaksanakan oleh para remaja yang mengikuti lomba dan kegiatan seni, tetapi juga dilaksanakan oleh seluruh remaja

\footnotetext{
${ }^{8}$ J.L.Ch. Abineno, Unsur-unsur Liturgia yang dipakai Gereja-gereja di Indonesia (Jakarta: 2011) hlm. 106.
} 
GMIM dalam setiap peribadatan remaja maupun jemaat.

\section{Kegiatan Natal Remaja GMIM}

Natal merupakan hari raya kelahiran Yesus Kristus bagi umat Kristiani. Bagi remaja GMIM, kegiatan natal merupakan salah satu wadah untuk mengekspresikan hal-hal kreatif melalui ibadah yang didalamnya terdapat nyanyian, musik iringan, drama, tarian dan sebagainya. Sehingga, natal juga didominasi dengan aktivitas bermusik remaja GMIM. Pada beberapa gereja di GMIM wilayah Amurang Dua, ibadah natal dipersiapkan dengan proses latihan drama musikal, penampilan solo, paduan suara dan tari-tarian. Umumnya, proses latihan untuk kegiatan natal remaja berkisar satu hingga dua bulan.

\section{Talent Show Remaja Teladan}

Remaja teladan merupakan program tahunan Komisi Pelayanan Remaja Sinode GMIM. Remaja teladan dilaksanakan ke dalam beberapa tahap, dengan acara puncak Grandfinal Remaja Teladan Sinode GMIM. Salah satu tahapan kegiatan remaja teladan adalah talent show. Pada tahapan ini menunjukkan adanya aktivitas bermusik remaja GMIM, melalui talent show menyanyi, bermain musik, musikalisasi puisi, band dan drama musikal.

\section{Keterlibatan remaja GMIM dalam proses apresiasi}

Berapresiasi berarti memberikan penilaian atau penghargaan bagi suatu objek. Remaja GMIM sebagai generasi penerus gereja menjadi tumpuan bagi keberlangsungan gereja, khususnya di kota Manado dan sekitarnya. Hal ini sejalan dengan Chrisnahanungkara ${ }^{9}$

\footnotetext{
${ }^{9}$ Ariel J. Chrisnahanungkara, "Gereja dan Pendidikan Seni Musik Bagi Anak", Jurnal Tonika Vol. 2 No. 1, 2019, hlm. 68.
}

dalam tulisannya yang menerangkan bahwa peran gereja tidak hanya melaksanakan pendidikan Kristen yang berkaitan dengan spiritualitas seseorang, tetapi gereja juga menjadi agen pendidikan seni dimana setiap aktivitas baik kegiatan ibadah maupun kegiatan gereja lainnya, tidak terpisah dari aktivitas bermusik. Dalam melaksanakan kegiatannya, remaja GMIM tentu melewati beberapa tahapan sehingga membuat remaja tersebut bergabung sebagai anggota remaja GMIM, dan anggota dari suatu kegiatan, misalnya anggota paduan suara, vokal grup, remaja teladan, panitia dan sebagainya. Disini pendidikan seni berfungsi untuk memberikan pengalaman estetik kepada remaja GMIM melalui proses apresiasi.

Kegiatan apresiasi diawali dengan
tahap mengamati. Sejalan dengan
Pandaleke dan Maragani (2019:28) dalam
artikelnya menyebutkan bahwa pengenalan awal atau deskripsi awal menjadi permulaan dari kegiatan apresiasi. $^{10}$ Tahap mengamati dalam proses apresiasi diwujudkan ketika para remaja diajak untuk mengikuti suatu kegiatan. Menurut beberapa pembina remaja GMIM, baik di wilayah Mapanget Satu dan Amurang Dua, bahwa remaja yang baru beralih dari statusnya sebagai Anak Sekolah Minggu (ASM) perlu diajak terlebih dahulu mengikuti beberapa kegiatan remaja yang melibatkan banyak orang, seperti paduan suara. Pada tahap ini, remaja didampingi pembina-pembina remaja untuk melihat kegiatan-kegiatan remaja, walaupun remaja tersebut belum sepenuhnya terlibat. Ini menjadi pengenalan awal bagi remaja GMIM.

\footnotetext{
${ }^{10}$ Stefanny M. Pandaleke \& Meyltsan H. Maragani, "Maengket Sebagai Sarana Pendidikan Seni Melalui Aktivitas Apresiatif dan Kreatif", Jurnal Geter Vol. 2 No. 1, 2019, hIm. 28.
} 
Tahap kedua, yaitu tahap penikmatan. Jazuli ${ }^{11}$ menjelaskan bahwa penikmatan ditandai dengan meningkatnya intensitas psikis subjek pada saat mengamati objek. Pada tahap ini, remaja GMIM mulai terlibat secara langsung dalam berbagai kegiatan tanpa didampingi pembina remaja setiap waktu. Ketika terlibat dalam paduan suara remaja, maka remaja tersebut lebih fokus dan serius mengikuti setiap latihan. Vokalisi dan lagu-lagu yang dipelajari dilaksanakan secara serius dengan mendengarkan instruksi pelatih. Lapian $\mathrm{dkk}^{12}$ menjelaskan bahwa latihan paduan suara merupakan suatu aktivitas berkesenian, yang digunakan sebagai media pendidikan. Hal ini menunjukkan bahwa telah terjadi penikmatan terhadap aktivitas paduan suara tersebut maupun aktivitas dalam kegiatan lainnya bagi anggota remaja GMIM yang terlibat.

Proses apresiasi berlanjut pada tahap selanjutnya, yaitu tahap pemahaman. Tahap pemahaman dimaksudkan ketika para remaja berusaha untuk mengidentifikasi dan menganalisis hal-hal unik, menarik dan yang berkesan. Pada tahap ini, remaja menganalisis keterlibatannya dalam kegiatan remaja yang diikuti. Para remaja mulai menganalisis proses latihan, cara melatih dari seorang pelatih, keberadaan pembina remaja hingga aktivitas latihan bersama teman-teman remaja lainnya. Ummah $\mathrm{dkk}^{13}$ menjelaskan bahwa masa remaja adalah masa dengan fase labil baik secara psikis dan emosi. Karena itu, cara

11 Jazuli, Paradigma Pendidikan Seni, (Semarang: 2016) hlm. 92.

${ }^{12}$ Alrik Lapian, Stefanny M. Pandaleke, Livie Dumondor, "Pendidikan Karakter dalam Proses Latihan Paduan Suara Remaja GMIM Exodus Paniki Dua", Jurnal Tumou Tou Vol. 5 No. 2, 2018, hlm. 141.

13 S.S. Ummah, Mosleh Habibullah, Hasan Basri, "Pembinaan Moral dan Kreativitas Remaja" Jurnal Nuansa Vol. 8 No. 1, 2011, hlm. 102. menganalisis seorang remaja dengan remaja lain bisa berbeda.

Seorang remaja bisa memahami bahwa proses latihan menyenangkan apabila latihan dilaksanakan secara singkat, tetapi remaja lain memahami bahwa menyenangkan itu apabila latihan dilaksanakan dengan waktu yang panjang. Ada juga remaja yang memahami bahwa vokalisi merupakan hal yang berkesan dan harus dilaksanakan sebelum memulai latihan inti, tetapi ada juga remaja yang memahami bahwa yang berkesan itu saat latihan lagu. Hal ini menunjukkan bahwa masing-masing remaja bisa memahami suatu proses berkegiatan dari sudut pandang yang berbeda.

Tahap selanjutnya adalah tahap penghayatan. Pada tahap ini, para remaja mulai berada dalam zona nyaman. Kenyamanan yang dimaksud adalah para remaja merasa bahwa kegiatan remaja merupakan suatu kebutuhan yang harus diikuti. Setiap proses latihan menjadi penting bagi para remaja. Ketika tidak ada latihan atau proses berkegiatan, atau ketika berhalangan latihan, maka remaja merasa ada satu aktivitas yang hilang dari dirinya. Ini mengindikasikan bahwa para remaja merasa menyatu dan luluh dengan situasi atau aktivitas berkegiatan remaja GMIM.

Pada tahap akhir, remaja GMIM melaksanakan kegiatan penilaian. Kegiatan penilaian ini merupakan tahapan akhir dari proses apresiasi. Disini remaja GMIM diajak untuk memberikan respons balik terhadap kegiatan yang diikuti, yakni paduan suara, vokal grup dan kegiatankegiatan seni lainnya. Tentu penilaian ini akan datang dari individu remaja atau secara berkelompok. Respons yang diberikan akan berbeda satu dengan yang lainnya, tergantung dari apresiasi masingmasing remaja GMIM terhadap kegiatan remaja tersebut. Seperti yang diungkapkan Jazuli bahwa kemampuan berparesiasi dapat diusahakan melalui 
berbagai pengalaman, kemudian di antara pengalaman tersebut dapat ditempuh dengan cara pembiasaan, belajar dan berkarya tentang seni. ${ }^{14}$

\section{Proses Kreatif Remaja GMIM melalui pendidikan musik}

Kreatif dalam ranah pendidikan seni merupakan hal yang vital, identik dengan kebebasan yang dapat dipertanggungjawabkan dan bertujuan untuk memampukan seseorang mencipta karya yang baru. Kreativitas berangkat dari kegiatan apresiasi, sehingga menimbulkan ide dan konsep untuk berpikir dan melakukan hal-hal kreatif. Pardede ${ }^{15}$ menjelaskan bahwa kreativitas mengacu pada produk, proses interaksi yang menghasilkan ide, pemikiran dan objek yang baru, sedangkan berpikir kreatif adalah upaya memaksimalkan kemampuan otak manusia untuk memikirkan ide-ide orisinal, beragam dan baru. Karena itu, kreativitas juga terlaksana sebagai lanjutan dari proses berpikir kreatif seseorang.

Seperti yang telah dijelaskan pada bagian pendahuluan, berpijak dari konsep apresiasi dan kreasi Jazuli dalam ranah pendidikan seni, serta teori Wallas mengenai proses berpikir kreatif, maka peneliti menguraikan tahapan pengembangan kreativitas remaja GMIM melalui pendidikan musik dilakukan melalui tahap preparation, tahap mengkonsep ide yang didasarkan pada kegiatan apresiasi dan tahap penuangan ide ke dalam bentuk kreativitas remaja GMIM. Tahap preparation merupakan tahapan awal yang pasti dilalui untuk menghasilkan kreativitas. Tahap ini

14 Jazuli, Paradigma Pendidikan Seni, (Semarang: 2016) hlm. 93.

${ }^{15}$ Parlindungan Pardede, "Berpikir Kritis dan Kreatif dalam Pendidikan Kristen", Jurnal Pendidikan Agama Kristen Regula Fidei Vol. 1 No. 1, 2016, hlm. 14. dilaksanakan dalam kegiatan apresiasi remaja GMIM melalui keterlibatan remaja dalam kegiatan-kegiatan remaja GMIM, termasuk kegiatan bermusik. Seperti yang telah dijelaskan pada proses apresiasi, remaja GMIM telah melewati beberapa tahapan apresiasi, sehingga remaja GMIM dapat mengumpulkan informasi dan mempelajari segala sesuatu mengenai kegiatan remaja melalui pengalaman nyata yang langsung dilakukan oleh remaja tersebut.

Tahap kedua adalah tahap mengkonsep ide yang berpijak pada proses apresiasi remaja GMIM. Pada tahap ini, remaja GMIM secara berkelompok mulai memikirkan ide-ide kreatif yang bisa dituangkan dalam ibadah-ibadah remaja, kegiatan-kegiatan remaja tingkat jemaat maupun lombalomba seni selanjutnya. Berdasarkan wawancara dengan beberapa remaja GMIM di wilayah Mapanget Satu, ide-ide dan konsep kreatif tercipta ketika para remaja saling berdiskusi tentang hal-hal yang telah dilaksanakan selama proses latihan maupun setelah lomba/kegiatan. Keinginan untuk terus berkarya secara bersama-sama menjadi tumpuan utama melakukan hal-hal baru bagi perkembangan remaja GMIM, khususnya pada tingkat jemaat dan wilayah.

Ide dan konsep tersebut juga didiskusikan bersama Komisi Pelayanan Remaja maupun pembina-pembina remaja lainnya. Seperti dijelaskan oleh Matheus dan Selfina ${ }^{16}$ dalam penelitiannya, bahwa pembina remaja bertindak sebagai pemimpin rohani sekaligus bertindak sebagai sahabat bagi remaja. Oleh karena itu, remaja GMIM selalu mendiskusikan ide-ide kreatif kepada pembina remaja, melalui

16 Jonathan Matheus \& Elisabet Selfina, "Peran Pembina Remaja Bagi Perkembangan Perilaku Remaja di Gereja Kemah Injil Indonesia Tanjung Selor Kalimantan Utara", Jurnal Jaffray Vol. 13 No. 1, 2015, hlm. 20. 
pertemuan rutin, tatap muka personal dan media sosial. Dengan harapan, ide-ide dan konsep para remaja dapat didorong dan disetujui untuk dilaksanakan.

Selanjutnya, para remaja menuangkan ide kreatif tersebut dalam tindakan nyata. Hal ini merupakan tahap penuangan ide ke dalam tindakan kreatif. Berdasarkan observasi, wawancara dan studi dokumen, maka berikut pengembangan kreativitas remaja GMIM yang dilaksanakan melalui proses pendidikan musik, didalamnya terdapat proses apresiasi.

Pertama, remaja GMIM membentuk kelompok mini choir. Berawal dari proses latihan paduan suara remaja di setiap jemaat, maka para remaja menemukan ide bahwa bernyanyi bersama-sama harus tetap ada dengan kemasan yang berbeda. Ini menjadi titik awal bagi remaja GMIM untuk berproses secara mandiri melalui mini choir atau paduan suara dengan anggota yang sedikit. Mini Choir ini dirancang sebagai wadah pelayanan remaja secara bersama-sama dalam setiap peribadatan. Berbekal latihan dari pelatih paduan suara profesional, para remaja berusaha untuk menjadi pelatih bagi teman-temannya.

Kedua, remaja GMIM merancang ibadah kreatif dan ibadah-ibadah natal dengan bekal proses-proses latihan sebelumnya. Berangkat dari kegiatan paduan suara, vokal grup, talent show dan sebagainya, maka remaja GMIM merancang jalannya peribadatan dengan pengisi-pengisi acara, seperti paduan suara, vokal grup, solo dan drama musikal. Drama musikal menjadi salah satu bentuk peribadatan kreatif maupun ibadah-ibadah natal yang sering dilaksanakan di kalangan remaja GMIM. Sementara sebagai pengiring ibadah, para remaja berlatih untuk membuat kelompok band.

Ketiga, remaja GMIM berusaha merancang bentuk-bentuk pencarian dana untuk mendukung kegiatan-kegiatan remaja jemaat. Pencarian dana yang dirancang dan dilaksanakan di kalangan remaja GMIM, umumnya dilakukan melalui kumantar atau kegiatan berjalan dari rumah ke rumah sambil bernyanyi bersama-sama, ngamen dengan cara bernyanyi atau bermain musik di tempattempat nongkrong dan lelang suara di peribadatan-peribadatan jemaat.

Keempat, melalui keterlibatan remaja GMIM dalam berbagai kegiatan remaja, baik dalam aktivitas bermusik maupun di luar aktivitas bermusik. Pengembangan kreativitas remaja GMIM juga diwujudkan dalam bentuk pekan kreativitas remaja. Pekan kreativitas remaja GMIM biasanya dilaksanakan di setiap jemaat GMIM. Pekan kreativitas remaja menampilkan berbagai kegiatan, diantaranya lomba bintang vokalia, busana gereja, berpacu dalam Kidung Jemaat, Cerdas Cermat Alkitab (CCA), emading dan sebagainya.

\section{Kesimpulan}

Pendidikan musik tidak hanya dilaksanakan pada lembaga pendidikan formal, tetapi juga pada lembaga non formal, termasuk gereja. Gereja sebagai agen pendidikan berpengaruh besar terhadap pertumbuhan dan perkembangan remaja. Sebagai remaja GMIM, aktivitas bermusik sangat melekat dalam kegiatan-kegiatan remaja di tingkat jemaat, wilayah dan sinode. Melalui proses apresiasi terhadap kegiatan remaja yang melibatkan aktivitas bermusik, maka remaja GMIM didorong untuk berpikir dan melakukan hal-hal kreatif. Makna pendidikan musik adalah memberikan pengalaman estetis melalui musik, dan pengalaman estetis tersebut diperoleh melalui kegiatan apresiasi dan kreasi. 


\section{Kepustakaan}

Abineno, J.L.Ch. 2011. Unsur-unsur Liturgia yang dipakai Gereja-gereja di Indonesia. Jakarta: Gunung Mulia.

Chrisnahanungkara. 2019. "Gereja dan Pendidikan Seni Musik Bagi Anak". Jurnal Tonika, Volume 2 No. 1 2019: 63-74.

Grafura dan Wijiyanti. 2019. Spirit Pedagogi di Era Disrupsi. Yogyakarta: Laksana.

Jazuli. 2016. Paradigma Pendidikan Seni. Semarang: CV. Farishma Indonesia.

Komisi Liturgi dan Musik Sinode GKI. 2012. Musik dalam Ibadah. Jakarta: Grafika KreasIndo.

Lapian, Alrik., Pandaleke, Stefanny M \& Dumondor, L. 2018. "Pendidikan Karakter dalam Proses Latihan Paduan Suara Remaja GMIM Exodus Paniki Dua". Jurnal Tumou Tou Volume 5 No. 2 2018: 136-145.

Lickona, Thomas. 2014. Pendidikan Karakter: Panduan Lengkap Mendidik Siswa Menjadi Pintar dan Baik. Bandung: Penerbit Nusa Media.

Matheus, Jonathan \& Selfina, E. 2015. "Peran Pembina Remaja Bagi Perkembangan Perilaku Remaja di Gereja Kemah Injil Indonesia Tanjung Selor Kalimantan Utara". Jurnal Jaffray Volume 13 No. 1 2015: 1-22.

Pandaleke, Stefanny Mersiany \& Maragani, Meyltsan H. 2019. "Maengket Sebagai Sarana Pendidikan Seni Melalui Aktivitas Apresiatif dan Kreatif". Jurnal Geter Volume 2 No. 1 2019: 24-31.

Pardede, Parlindungan. 2016. "Berpikir dan Kreatif dalam Pendidikan Kristen". Jurnal Pendidikan Agama Kristen Regula Fidei, Volume 1 No. 1 2016: 1-32.
Rusdi. 2017. “'Implementasi Teori Kreativitas Graham Wallas dalam Sekolah Kepenulisan di Pesantren Mahasiswa Hasyim Asy'ari Cabeyan Yogyakarta". Jurnal Muslim Heritage, Volume 2 No. 2 2017: 259-273.

Sunarto. $2018 . \quad$ "Pengembangan Kreativitas-Inovatif dalam Pendidikan Seni Melalui Pembelajaran Mukidi". Jurnal Refleksi Edutika, Volume 8 No. 2 2018: 107-113.

Ummah, S.S., Habibullah \& Basri. 2011. "Pembinaan Moral dan Kreativitas Remaja" Jurnal Nuansa, Volume 8 No. 1 2011: hlm. 101-122.

Wallas, Graham. 2014. The Art of Thought. England: Solis Press. 